\title{
Temporal variations in fatty acid composition of deep-sea holothurians: evidence of bentho-pelagic coupling
}

\author{
Ian R. Hudson ${ }^{1, *}$, David W. Pond ${ }^{2}$, David S. M. Billett ${ }^{1}$, Paul A. Tyler ${ }^{1}$, \\ Richard S. Lampitt ${ }^{1}$, George A. Wolff ${ }^{3}$
}
${ }^{1}$ Southampton Oceanography Centre, George Deacon Division and University of Southampton, School of Ocean and Earth Science, Empress Dock, Southampton SO14 3ZH, UK
${ }^{2}$ British Antarctic Survey, Madingley Road, Cambridge CB3 0ET, UK
${ }^{3}$ Environmental Organic Chemistry and Geochemistry Group, Oceanography Laboratories, Department of Earth and Ocean Sciences, University of Liverpool, Liverpool L69 3BX, UK

\begin{abstract}
Fatty acid biomarkers were used to examine the diet of deep-sea holothurians. We collected 3 species from the Porcupine Seabight and Porcupine Abyssal Plain, NE Atlantic, between 800 and $4850 \mathrm{~m}$ in August 2001 (summer), March 2002 (pre-spring bloom), and October 2002 (autumn). Of these, 2 species, the abyssal Amperima rosea and the bathyal Bathyplotes natans, showed significant variations in fatty acid compositions. These are likely to be seasonal. Polyunsaturated fatty acids (PUFAs) were dominant within muscle tissue of both species during August 2001 and October 2002, in particular 20:4 (n-6), 20:5 (n-3) and 22:6 (n-3). During March 2002, prior to the spring bloom, there were substantially lower proportions of PUFAs in both species, and increased amounts of mono-unsaturated fatty acids (monoenes), particularly the bacterially-derived biomarkers 18:1 (n-7) and non-methyl uninterrupted dienes (NMIDs). In contrast, the fatty acid composition of the third species, the abyssal Deima validum, remained relatively stable, with muscle tissue containing a high proportion of PUFAs during pre- and post-spring-bloom periods. A further 6 species were sampled in March 2002 and October 2002. Across all these species, 3 patterns of fatty composition were evident: (1) Laetmogone violacea had higher proportions of PUFAs in October than in March; (2) Psychropotes longicauda and Benthogone rosea had lower proportions of PUFAs in October than in March; (3) Deima validum, Oneirophanta mutabilis, Paroriza pallens and P. prouhoi had unchanged fatty acid compositions during these contrasting periods. These differences may be related to the varying reproductive strategies of the species. The implications of changes in fatty acids for reproductive processes, and how these could be factors determining allocation of lipid resources in gonads, is discussed.
\end{abstract}

KEY WORDS: Holothurian $\cdot$ Deep sea $\cdot$ Bentho-pelagic coupling $\cdot$ Seasonal flux $\cdot$ NE Atlantic $\cdot$ Lipids

\section{INTRODUCTION}

Mobile epibenthic deposit-feeders, in particular holothurians, are important members of the benthic fauna in the deep sea (Billett 1991). Holothurians dominate the invertebrate megafauna in many areas of the deep sea in terms of both number and biomass (Sibuet et al. 1984, Billett 1991, Billett et al. 2001). Many of these echinoderms feed on the top few millimetres of the seabed, ingesting freshly deposited phytodetritus and organic matter (OM) (Massin 1982). Bathyal holothurians such as Laetmogone violacea, Paroriza pallens and Bathyplotes natans are common in the Porcupine Seabight (Billett 1991). Paradoxically, less is known, perhaps, about the biology of these bathyal holothurians than their abyssal relatives in the NE Atlantic, although the reproductive biology of several species has been described (Tyler et al. 1985, 1994). The benthic 
community in the Porcupine Abyssal Plain is dominated by over 10 species of deposit-feeding holothurians ranging from the infaunal Molpadia blakei to the benthopelagic Peniagone diaphana (Billett et al. 2001).

Biophysical processes in the upper ocean photic zone drive the succession of phytoplankton populations (Raymont 1980). The different phytoplankton species will influence the chemical composition of any detrital material created, which will be modified further by the actions of mesozooplankton (Mayzaud et al. 1999) and gelatinous macrozooplankton (Pfannkuche \& Lochte 1993, de Wilde et al. 1998).

The ways in which the detritus is produced and reprocessed before it reaches the seafloor could play a major role in structuring deep-sea communities (Billett et al. 1983, 2001, Hudson et al. 2003) through the modification of detrital flux into a variety of different biochemical components (Kiriakoulakis et al. 2001), thus creating a wide range of food sources that can be exploited differentially by the benthos (Ginger et al. 2001).

The discovery of seasonal phytodetrital fluxes and the deposition of phytodetritus on the sea floor (Billett et al. 1983) and more recently in abyssal locations in the tropical Pacific (See review by Beaulieu 2002) highlight the role of OM flux in open-ocean areas. In the northeast Atlantic, blooms of phytoplankton occur in the spring and summer (Ducklow \& Harris 1993 and references therein). The variability in magnitude, timing (Lampitt et al. 2001) and species composition of seasonal phytoplankton blooms varies interannually. Seasonal fluxes of OM play a key role in the nutrition and reproduction of many epibenthic feeders in the deep sea (Billett 1991, Gooday 2002) and in many cases represent the major food source. Understanding the way this detrital food resource is allocated to different physiological functions within a species may explain why seasonal fluxes play a crucial role in the structure of the benthic community via bentho-pelagic coupling.

Biomarkers have proved to be useful tools in understanding deep-ocean food chains (Ginger et al. 2001). Fatty acids are particularly useful biomarkers for identification of macro- and microplankton species and their contribution to animal diets (Sargent et al. 1987, Virtue et al. 2000). They are easy to extract and there is a large database of lipid components taken from pure strains of many marine organisms (Sargent et al. 1987). Lipids are useful for tracing the origins of food within complex food webs (Iken et al. 2001) and gaining biomass measurements using sterols (Ginger et al. 2001) and fatty acids (Sargent et al. 1987). This provides the basis for tracing the signal of phytoplankton flux through the water column into sediments. Here, deposit-feeders consume the detrital material and this can be traced back to specific algal sources in the upper ocean (Harvey \& Johnston 1995, Pond et al. 1998) by examining the fatty acids present in the gut contents and body tissues. Key biomarkers include the polyunsaturated fatty acids (PUFAs) 20:5 (n-3) and 22:6 (n-3), common to many types of micro- and macroalgae. PUFAs are useful lipid fractions; they have easyto-modify, stable molecular structures, creating a very distinct signature that allows accurate identification of their various sources. Bacterially derived markers are also important, such as 18:1 (n-7) and non-methyl interrupted dienes (NMIDs) (see review table by Howell et al. 2003). These fatty acids are common in sediments and are characteristic of organic matter that has been modified and reworked by microbial communities. The fact that basic lipid compounds can be transformed and modified into a wide range of different components makes them important in tracing resource allocation processes in surficial sediments.

Examining the differences in composition of these biochemical markers in a range of holothurian species that are unable to biosynthesise their own fatty acids should demonstrate whether or not deposit-feeding holothurians have a species-specific biochemistry, derived from either differences in their food sources, growth and assimilation, or reproductive processes. Holothurians rely upon OM fluxes to the sea floor to supply their natural diet with essential lipids and pigments they are unable to biosynthesise de novo (Ginger et al. 2001). Many holothurian species utilise fatty acids as reproductive precursors, which are important for successful development and growth (Hudson et al. 2003).

Deep-sea holothurians have different reproductive strategies (Hansen 1975, Billett 1991, Tyler \& Young 1992). The way in which a species allocates food reserves into the muscle and/or into the gonad at times of reproductive need is likely to vary according to the reproductive pattern and development mode of the species. Different species may have contrasting compositions at different times of year that could be specific to their reproductive patterns.

The aim of this study was to investigate a range of bathyal and abyssal holothurian species to determine (1) their fatty acid compositions, (2) temporal changes in fatty acids, and (3) the possible relationship between fatty acid composition and reproductive patterns in individual species.

\section{MATERIALS AND METHODS}

Study area and sampling. The Porcupine Seabight (PSB) and Porcupine Abyssal Plain (PAP) (Fig. 1) in the NE Atlantic lie within an area with seasonal pulses of phytodetritus (Billett et al. 1983, Rice et al. 1991, 
Lampitt et al. 2001, Gooday 2002). Samples were collected using a semi-balloon otter trawl (OTSB) (Merrett \& Marshall 1981) between 14 August and 12 September 2001, 2 and 20 March 2002, and 26 September and 26 October 2002 (Table 1). Samples collected in summer 2001 were taken shortly after the annual flux of phytodetritus (Lampitt et al. 2001), a post-bloom period. Samples collected in early spring 2002 were taken during the pre-bloom period (Lampitt \& Antia 1997), and samples collected in early autumn 2002, were taken after the final spring/summer blooms. This sampling strategy allowed an investigation of potential seasonal changes in muscle fatty acid compositions of a range of holothurian species. We sampled, 3 species, Amperima rosea, Bathyplotes natans and Deima validum in all 3 periods. A further 6 species, Psychropotes longicauda, Oneirophanta mutabilis, Paroriza prouhoi, Benthogone rosea, Laetmogone violacea and Paroriza pallens were sampled only in March and October 2002.

Immediately after trawl retrieval, holothurians that were in good condition were placed into pre-chilled seawater $\left(4^{\circ} \mathrm{C}\right)$ and transferred to a constant temperature laboratory $\left(4^{\circ} \mathrm{C}\right)$ for dissection. Muscle samples were removed from 2 of the longitudinal bands. These bands

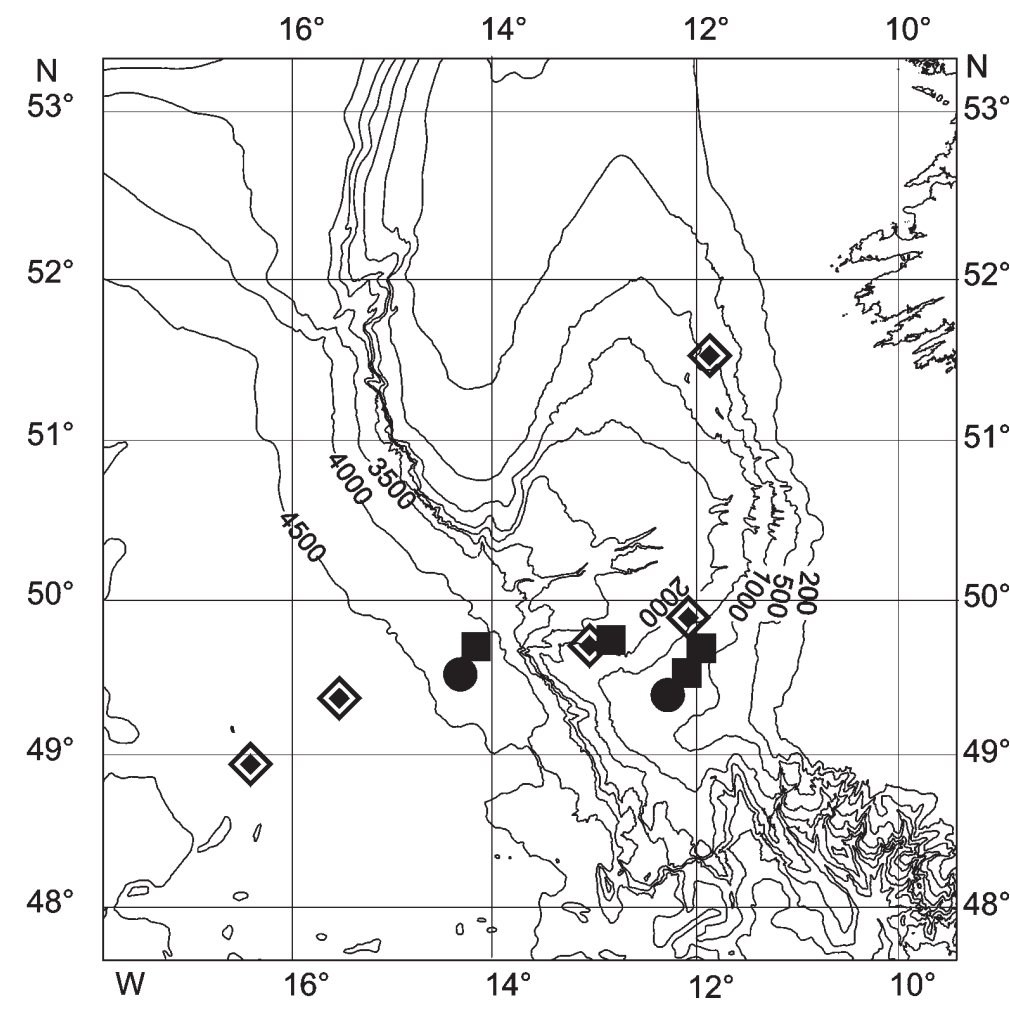

Fig. 1. Bathymetric chart of Porcupine Seabight and Porcupine Abyssal Plain, NE Atlantic Ocean, showing sampling locations in August 2001 $(\bullet)$, March $2002(\mathbf{\square})$, October $2002(\diamond)$

Table 1. Summary of species trawl-sample locations, with positions recorded at trawl start points. n: no. of samples

\begin{tabular}{|c|c|c|c|c|c|c|}
\hline Station & $\begin{array}{c}\text { Date } \\
\text { (dd/mm/yy) }\end{array}$ & $\begin{array}{l}\text { Latitude } \\
\quad\left({ }^{\circ} \mathrm{N}\right)\end{array}$ & $\begin{array}{l}\text { Longitude } \\
\left({ }^{\circ} \mathrm{W}\right)\end{array}$ & $\begin{array}{l}\text { Depth range } \\
(\mathrm{m})\end{array}$ & Species & $\mathrm{n}$ \\
\hline \multicolumn{7}{|c|}{ RRS ‘Discovery’ cruise 255} \\
\hline \multirow[t]{2}{*}{$14158 \# 1$} & $28 / 08 / 01$ & $49^{\circ} 32^{\prime}$ & $14^{\circ} 23^{\prime}$ & $4286-4311$ & $\begin{array}{l}\text { Amperima rosea } \\
\text { Deima validum }\end{array}$ & $\begin{array}{l}7 \\
5\end{array}$ \\
\hline & $29 / 08 / 01$ & $49^{\circ} 27^{\prime}$ & $12^{\circ} 14^{\prime}$ & $1340-1397$ & Bathyplotes natans & 5 \\
\hline \multicolumn{7}{|c|}{ RRS ‘Discovery' cruise 260} \\
\hline 14309 \# 1 & $16 / 03 / 02$ & $49^{\circ} 43^{\prime}$ & $13^{\circ} 10^{\prime}$ & $2011-2218$ & Benthogone rosea & 5 \\
\hline \multirow[t]{4}{*}{$14317 \# 1$} & $19 / 03 / 02$ & $49^{\circ} 39^{\prime}$ & $14^{\circ} 15^{\prime}$ & $4190-4263$ & Amperima rosea & 5 \\
\hline & & & & & Paroriza prouhoi & 5 \\
\hline & & & & & Deima validum & 5 \\
\hline & & & & & Psychropotes longicauda & 5 \\
\hline 14323 \# 1 & $21 / 03 / 02$ & $49^{\circ} 36^{\prime}$ & $12^{\circ} 11^{\prime}$ & $1419-1440$ & Bathyplotes natans & 5 \\
\hline \multirow{2}{*}{14325 \# 1} & $22 / 03 / 02$ & $49^{\circ} 40^{\prime}$ & $11^{\circ} 55^{\prime}$ & $1100-1119$ & Paroriza pallens & 5 \\
\hline & & & & & Laetmogone violacea & 5 \\
\hline \multicolumn{7}{|c|}{ RRS ‘Discovery’ cruise 266} \\
\hline \multirow[t]{2}{*}{15051 \# 1} & $01 / 10 / 02$ & $51^{\circ} 26^{\prime}$ & $11^{\circ} 54^{\prime}$ & $1033-1039$ & Bathyplotes natans & 5 \\
\hline & & & & & Laetmogone violacea & 5 \\
\hline \multirow[t]{3}{*}{$15054 \# 6$} & $03 / 10 / 02$ & $48^{\circ} 57^{\prime}$ & $16^{\circ} 17^{\prime}$ & $4841-4844$ & Amperima rosea & 5 \\
\hline & & & & & Psychropotes longicauda & 5 \\
\hline & & & & & Paroriza prouhoi & 5 \\
\hline 15055 \# 2 & $12 / 10 / 02$ & $49^{\circ} 25^{\prime}$ & $15^{\circ} 25^{\prime}$ & $4741-4813$ & Deima validum & 5 \\
\hline 15058 \# 1 & $14 / 10 / 02$ & $49^{\circ} 40^{\prime}$ & $13^{\circ} 01^{\prime}$ & 1992-2040 & Benthogone rosea & 5 \\
\hline 15066 \# 1 & $19 / 10 / 02$ & $49^{\circ} 50^{\prime}$ & $12^{\circ} 05^{\prime}$ & $1240-1360$ & Paroriza pallens & 5 \\
\hline \multicolumn{7}{|c|}{ Sediment traps } \\
\hline \multirow[t]{2}{*}{$55102 \# 2$} & 2000 & $48^{\circ} 58^{\prime}$ & $16^{\circ} 25^{\prime}$ & 3000 & & \\
\hline & 2001 & $48^{\circ} 58^{\prime}$ & $16^{\circ} 26^{\prime}$ & 3000 & & \\
\hline 15053 \# 1 & 2002 & $48^{\circ} 59^{\prime}$ & $16^{\circ} 27^{\prime}$ & 3000 & & \\
\hline
\end{tabular}


are the major muscular components of a holothurian and are a likely storage site of lipid. All samples were frozen at $-70^{\circ} \mathrm{C}$. Muscle tissue was chosen for the determination of fatty acid profiles because fatty acid analyses from gut sediments and gut-wall tissue have proved to be unreliable, perhaps because of cell lysis, as suggested by Ginger et al. (2001).

Fatty acid extraction. Total lipid was extracted from holothurian muscle tissue using chloroform:methanol (2:1 vol:vol) (Folch et al. 1957). Following filtration, aliquots of total lipid were transesterfied in methanol containing $1.5 \%$ sulphuric acid at $50^{\circ} \mathrm{C}$ for $16 \mathrm{~h}$ to produce fatty acid methyl esters (FAME; Christie 1982). FAME were purified using thin-layer chromatography in a hexane:diethyl ether:acetic acid (90:10:1 vol:vol:vol) solvent system. Purified FAME were dissolved in hexane at a concentration of $2 \mathrm{mg} \mathrm{ml}^{-1}$. The samples were analysed using gas chromatography, Resteck Stabilwax (GC) on a 5360 Mega series (Carlo Erba, Milan) run on a Restek Stabilwax fused-silica capillary column $(30 \mathrm{~m} \times 0.32 \mathrm{~mm}$ inner diameter) with a hydrogen gas carrier. FAME were identified after integration by comparison of retention time of peaks with characterised standards (Pond et al. 1998).

Data analysis. The method used did not allow the calculation of absolute values for each fatty acid. Therefore the fatty acid values from muscle tissue are expressed as percentage composition. Statistical analysis using multivariate approaches was carried out using non-transformed data (Howell et al. 2003). BrayCurtis similarity indices and analysis of similarity (ANOSIM) were calculated and analysed by multidimensional scaling (MDS) displaying bubble plots showing the relative percentage of each fatty acid selected, using PRIMER 5 (Clarke \& Warwick 1994). In addition, 1-way analyses of variance (ANOVA) were carried out on Box-Cox transformed data, to allow for normality of data and homogeneity of variances.

\section{RESULTS}

The fatty acid compositions of 3 holothurian species, Amperima rosea, Deima validum and Bathyplotes natans, collected in August 2001 and October 2002, were dominated by polyunsaturated fatty acids (PUFAs) (Fig. 2). In both A. rosea and B. natans this pattern was mainly because of high levels of 20:5 (n-3) (Table 2). In March 2002, in contrast, PUFAs were proportionally much lower. A. rosea showed a significant change in 20:5 (n-3) $(F=170.6$, df $=2,12, \mathrm{p}<0.001)$, but did not show changes in the levels of 20:4 (n-6) $(F=2.38$, df $=$ $2,12, \mathrm{p}<0.05)$. Changes in both 20:4 (n-6) $(F=164.8$, $\mathrm{df}=2,12, \mathrm{p}<0.001)$ and $20: 5(\mathrm{n}-3)(F=178.1, \mathrm{df}=2,12$, $\mathrm{p}<0.001)$ were noted in $B$. natans.
Concomitant with the decrease in the proportion of PUFAs, Amperima rosea and Bathyplotes natans had greater proportions of monoenes in their total fatty acid profiles during March 2002 than in August 2001 and October $2002(F=4.16$, df $=1,20, \mathrm{p}<0.05)$ (Fig. 2). The main monoenes were 24:1 (n-9) and 18:1 (n-7) in $A$. rosea and 14:1 and 18:1 (n-7) in B. natans (Table 2). The increase in the proportions of monoenes in the March period may have been the result of a decline in

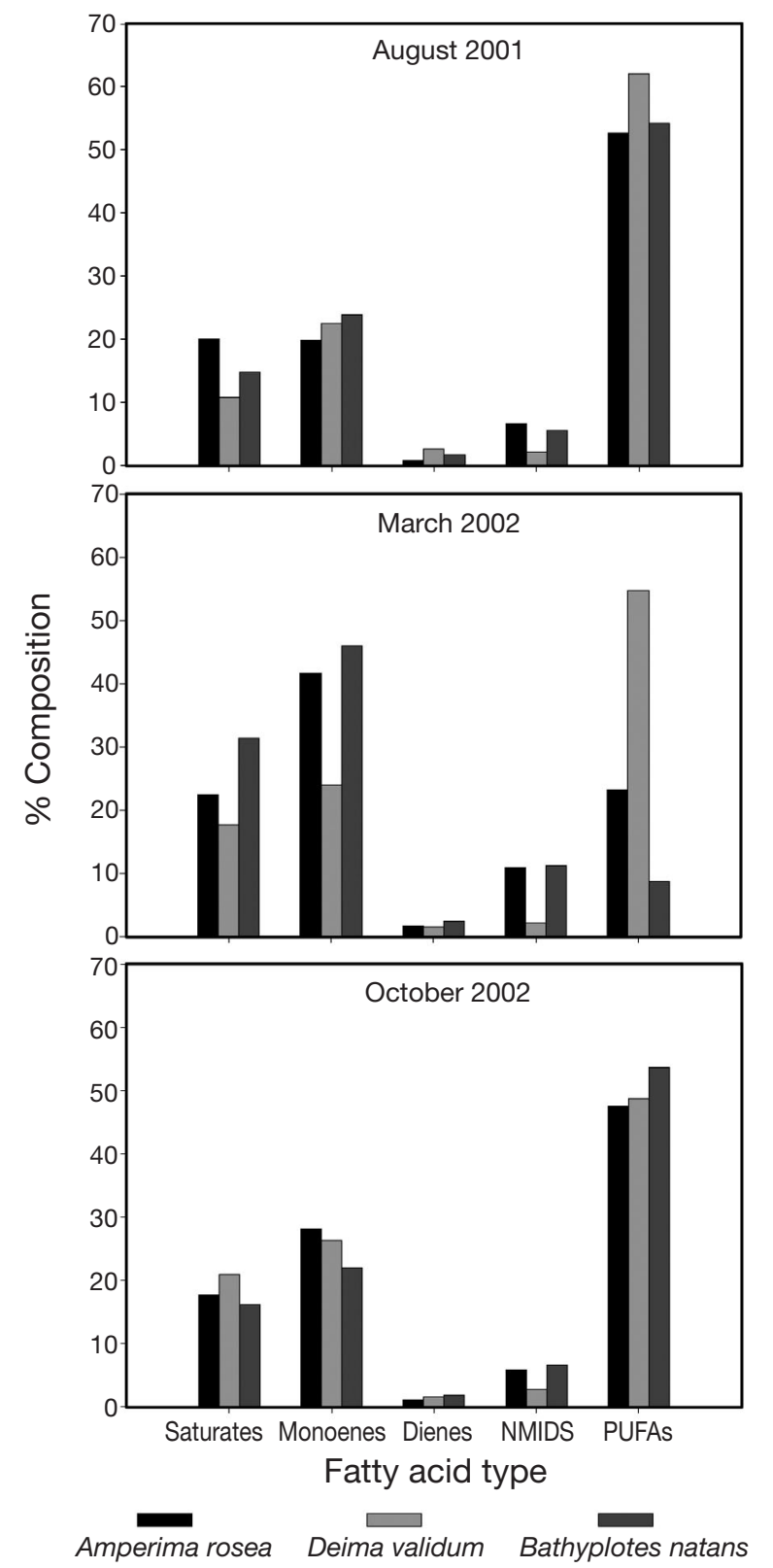

Fig. 2. Amperima rosea, Deima validum, Bathyplotes natans. Percentage composition of fatty acid types in muscle tissue from holothurians sampled in August 2001, March 2002 and October 2002. NMIDS: non-methyl uninterrupted dienes; PUFAs: polyunsaturated fatty acids 
Table 2. Amperima rosea, Deima validum, Bathyplotes natans. Mean (SD) percentage fatty acid compositions. NMIDS: non-methyl uninterrupted dienes; PUFAs: polyunsaturated fatty acids; DMA: dimethylacetate

\begin{tabular}{|c|c|c|c|c|c|c|c|c|c|c|c|c|c|c|c|c|c|c|}
\hline \multirow[t]{3}{*}{ Fatty acid } & \multicolumn{6}{|c|}{$\longrightarrow$ Amperima rosea } & \multicolumn{6}{|c|}{ Deima validum } & \multicolumn{6}{|c|}{ - Bathyplotes natans } \\
\hline & \multicolumn{2}{|c|}{ Aug 01} & \multicolumn{2}{|c|}{ Mar 02} & \multicolumn{2}{|c|}{ Oct 02} & \multicolumn{2}{|c|}{ Aug 01} & \multicolumn{2}{|c|}{ Mar 02} & \multicolumn{2}{|c|}{ Oct 02} & \multicolumn{2}{|c|}{ Aug 01} & \multicolumn{2}{|c|}{ Mar 02} & \multicolumn{2}{|c|}{ Oct 02} \\
\hline & $\bar{x}$ & $\mathrm{SD}$ & $\bar{X}$ & $\mathrm{SD}$ & $\bar{X}$ & $\mathrm{SD}$ & $\bar{x}$ & $\mathrm{SD}$ & $\bar{x}$ & $\mathrm{SD}$ & $\bar{x}$ & $\mathrm{SD}$ & $\bar{X}$ & $\mathrm{SD}$ & $\bar{x}$ & $\mathrm{SD}$ & $\bar{x}$ & $\mathrm{SD}$ \\
\hline $14: 1$ & 0.50 & 0.34 & 1.63 & 0.79 & 0.61 & 0.07 & 0.46 & 0.26 & 0.74 & 0.50 & 1.28 & 0.14 & 1.89 & 1.52 & 8.36 & 1.66 & 1.70 & 0.22 \\
\hline $15: 0$ & 0.35 & 0.26 & 1.34 & 0.50 & 0.33 & 0.18 & 0.40 & 0.35 & 1.22 & 0.34 & 1.11 & 0.09 & 1.31 & 0.25 & 2.51 & 0.42 & 0.77 & 0.13 \\
\hline 16:0 DMA & 0.75 & 0.33 & 0.81 & 0.44 & 0.45 & 0.14 & 0.67 & 0.27 & 1.06 & 0.40 & 0.93 & 0.11 & 1.54 & 0.20 & 3.05 & 0.67 & 0.88 & 0.10 \\
\hline $16: 1(n-5)$ & 0.93 & 0.09 & 4.10 & 1.20 & 1.53 & 0.28 & 0.17 & 0.14 & 1.00 & 0.10 & 3.42 & 0.19 & 2.44 & 0.80 & 1.14 & 0.78 & 0.87 & 0.14 \\
\hline $16: 1(n-7)$ & 3.40 & 0.68 & 1.36 & 0.95 & 0.97 & 0.13 & 1.00 & 0.26 & 0.61 & 0.13 & 1.20 & 0.14 & 0.10 & 0.00 & 4.42 & 1.08 & 1.26 & 0.29 \\
\hline $18: 0$ & 8.68 & 1.59 & 6.67 & 1.11 & 4.73 & 0.53 & 3.74 & 0.89 & 4.86 & 1.13 & 4.67 & 0.19 & 5.89 & 0.89 & 13.58 & 2.40 & 5.70 & 0.15 \\
\hline $18: 1(n-9)$ & 3.21 & 0.54 & 3.42 & 0.43 & 6.57 & 1.61 & 3.43 & 1.53 & 2.30 & 0.22 & 5.60 & 0.17 & 3.82 & 0.66 & 4.60 & 0.49 & 3.31 & 0.40 \\
\hline $18: 1(n-7)$ & 5.25 & 0.85 & 10.05 & 2.39 & 3.68 & 0.64 & 6.36 & 1.84 & 4.67 & 0.33 & 3.48 & 0.13 & 5.86 & 1.12 & 14.46 & 2.68 & 5.63 & 0.63 \\
\hline $18: 1(n-5)$ & 0.05 & 0.06 & 0.69 & 0.56 & 1.02 & 0.14 & 0.85 & 0.28 & 1.65 & 0.38 & 1.16 & 0.05 & 0.50 & 0.33 & 2.39 & 0.36 & 0.71 & 0.08 \\
\hline $18: 2(n-6)$ & 0.80 & 0.93 & 1.71 & 0.59 & 0.99 & 0.12 & 2.61 & 1.10 & 1.54 & 0.38 & 1.44 & 0.37 & 1.65 & 1.30 & 2.50 & 1.64 & 1.75 & 0.37 \\
\hline 20:4(n-6) & 11.86 & 2.61 & 13.26 & 5.47 & 13.85 & 0.57 & 29.54 & 2.66 & 26.30 & 0.75 & 20.08 & 0.81 & 14.15 & 1.71 & 4.05 & 3.87 & 19.21 & 0.74 \\
\hline $20: 5(n-3)$ & 26.59 & 3.98 & 6.42 & 3.37 & 22.86 & 2.39 & 27.40 & 0.55 & 22.80 & 1.98 & 22.91 & 0.99 & 22.41 & 1.95 & 0.10 & 0.07 & 21.35 & 1.79 \\
\hline $22: 0$ & 1.72 & 0.49 & 2.57 & 0.73 & 2.59 & 0.38 & 0.14 & 0.07 & 4.39 & 0.55 & 4.66 & 0.28 & 0.22 & 0.23 & 0.52 & 0.32 & 3.26 & 0.20 \\
\hline $22: 1(n 7+9)$ & 1.12 & 0.16 & 1.14 & 0.00 & 1.80 & 0.29 & 1.56 & 0.19 & 3.38 & 0.00 & 1.68 & 0.25 & 1.59 & 0.33 & 3.61 & 0.00 & 2.37 & 0.18 \\
\hline $22: 2 \Delta 7,5$ & 6.07 & 0.67 & 10.99 & 0.27 & 5.26 & 0.51 & 1.22 & 0.17 & 1.97 & 0.14 & 2.11 & 0.09 & 3.37 & 0.69 & 8.67 & 1.06 & 5.29 & 0.71 \\
\hline $22: 5(n-3)$ & 2.26 & 0.43 & 0.71 & 3.5 & 1.32 & 0.1 & 0.95 & 0.11 & 0.91 & & 1.06 & 0.16 & 2.88 & 0.41 & 0.14 & 3.8 & 2.19 & 0.13 \\
\hline $22: 6(n-$ & 12.01 & 5.53 & 2.79 & 1.9 & 9.45 & 1.0 & 4.17 & 0.4 & 4.77 & & 4.76 & & 14.82 & 0.87 & 4.49 & 0.6 & 11.00 & 0.71 \\
\hline $24: 1(n-9)$ & 3.07 & 3.16 & 11.10 & 2.40 & 6.79 & 0.95 & 3.67 & 0.30 & 3.67 & 0.40 & 3.69 & 0.15 & 2.80 & 0.98 & 0.07 & 0.08 & 1.81 & 0.21 \\
\hline & & 4.81 & & & & & & & & & & & & & & & & 1.29 \\
\hline Monoenes & 19.84 & 6.56 & 41.71 & 15.40 & 28.12 & 5.34 & 22.45 & 6.87 & 23.94 & 2.74 & 26.19 & 1.52 & 23.81 & 7.83 & 46.01 & 10.13 & 21.90 & 2.84 \\
\hline Dienes & 0.80 & 0.93 & 1.71 & 0.59 & 0.99 & 0.12 & 2.61 & 1.10 & 1.54 & 0.38 & 1.44 & 0.37 & 1.65 & 1.30 & 2.50 & 1.64 & 1.75 & 0.37 \\
\hline NMIDS & 6.67 & 0.89 & 10.99 & 0.27 & 5.74 & 0.60 & 2.06 & 0.54 & 2.07 & 0.20 & 2.65 & 0.13 & 5.52 & 1.52 & 11.28 & 1.86 & 6.55 & 0.86 \\
\hline
\end{tabular}

the proportions of PUFAs, although variation in saturates and monoenes were not the same within species, which indicates actual variation in monoene fatty acid composition.

Deima validum was different, and maintained high proportions of PUFAs throughout all sampling periods. PUFAs 20:4 (n-6) and 20:5 (n-3) occurred in similar proportions. The proportions of monoenes also remained similar in all sampling periods for this species (Fig. 2, Table 2).

Analysis of Bray-Curtis similarities showed a distinct trend in fatty acid profiles of Amperina rosea and Bathyplotes natans, with significant differences in fatty acid compositions of both species between the pre- and post-bloom sampling periods. The MDS ordinations and bubble plots for the levels of 20:5 (n-3) in A. rosea (Fig. 3) and $B$. natans (Fig. 4) show that the tempo-

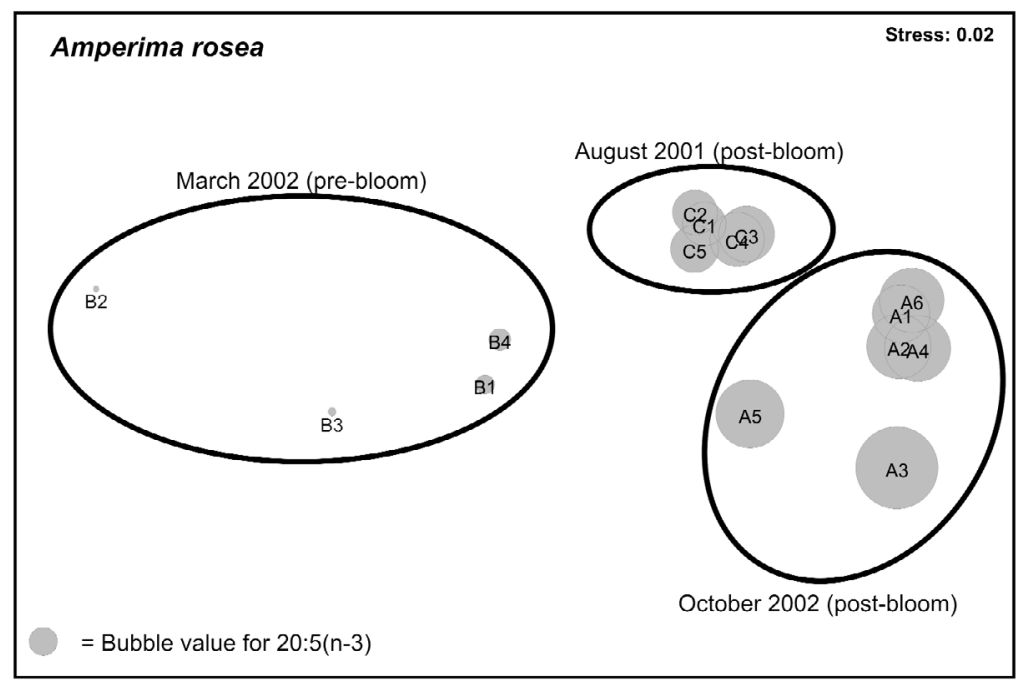

Fig. 3. Amperima rosea. Multidimensional scaling plot of fatty acid composition (\%) extracted from muscle tissue of samples taken in August 2001 (C1-5), March 2002 (B1-4) and October 2002 (A1-6). Bubble plot values for relative percentage composition of PUFA 20:5(n-3) are shown 


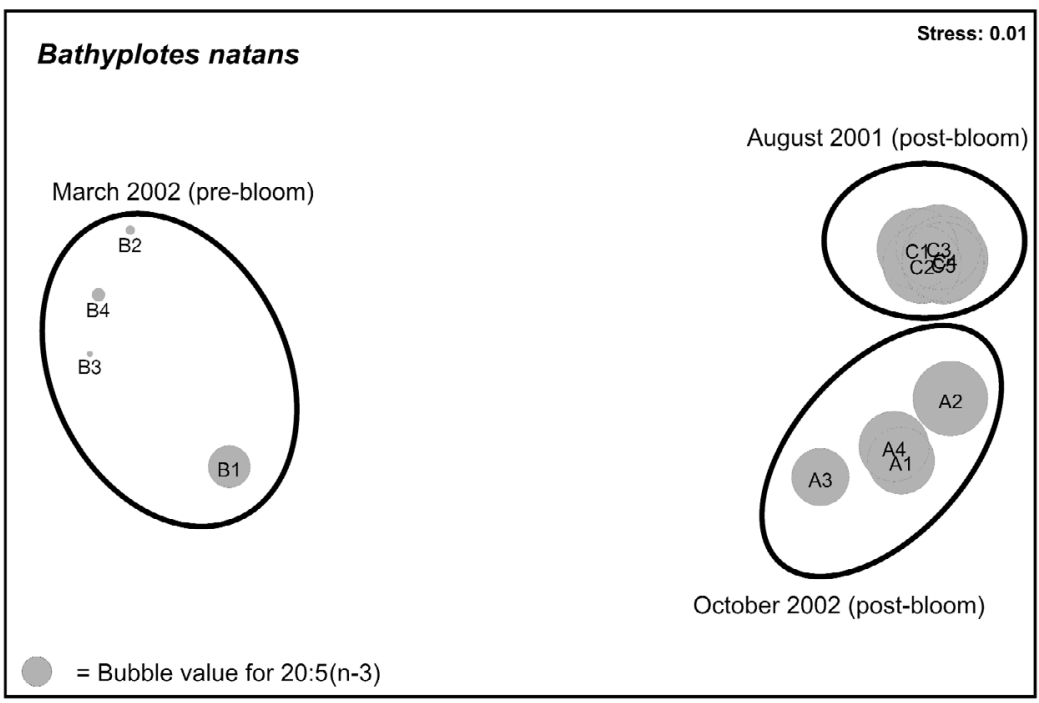

Fig. 4. Bathyplotes natans. Multidimensional scaling plot of fatty acid composition (\%) extracted from muscle tissue of samples taken in August 2001 (C1-5), March 2002 (B1-4) and October 2002 (A1-4). Bubble plot values for relative percentage composition of PUFA 20:5(n-3) are shown
A similar pattern to that in Deima validum was observed in Oneirophanta mutabilis. There were no major differences in the PUFAs, but unlike $D$. validum there were slightly higher proportions of saturates and lower proportions of monoenes in the post-bloom period. However, they were not significant (Fig. 6). As with Bathyplotes rosea, Psychropotes longicauda showed a reversal in the pattern of PUFAs, with higher proportions of PUFAs in the pre-bloom period as a result of lower levels of 20:4 (n-6) in the post-bloom ( $F=$ 215.3, df $=1,8, p<0.001)$. This caused an apparent increase in the proportion of saturates and monoenes (Table 4). This trend was also observed in Paroriza prouhoi, for which PUFA proportions were high in the ral pattern in fatty acid composition is driven by changes in the amounts of total PUFA. In the March pre-bloom period PUFAs were reduced by a factor of $\sim 2$ in A. rosea and a factor of $\sim 6$ in B. natans in comparison with August 2001 and October 2002 (Table 2).

A number of species were sampled only in March 2002 and October 2002. These included 3 bathyal and 3 abyssal species (Table 1 ).

Laetmogone violacea had a pattern similar to that of Bathyplotes natans, with high proportions of PUFAs during the post-bloom period and low proportions during the pre-bloom period (Fig. 5), although the changes were not as pronounced as in B. natans. The dominant fatty acids in $L$. violacea during the postbloom period were the PUFAs 20:4 (n-6) and 20:5 (n-3) (Table 3). In the pre-bloom period levels of 20:5 (n-3) were reduced $(F=4.36$, df $=1,8, \mathrm{p}<0.001)$, while levels of 20:4 (n-6) remained the same $(F=0.51$, df $=$ $1,8, \mathrm{p}>0.05)$. Proportions of monoenes and saturates were higher in March 2002 as a result.

Benthogone rosea showed the opposite pattern. High proportions of PUFAs occurred during the prebloom period and low proportions during the postbloom period (Fig. 5). This pattern was driven by a reduction in the overall proportions of both 20:5 (n-3) and 20:4 (n-6). Paroriza pallens showed little variation in fatty acid composition over the 2 sampling periods $(F=0.01, \mathrm{df}=1,48, \mathrm{p}>0.1)$. The only change was a slightly higher proportion of saturates in the pre-bloom period caused, for the most part, by an increase in 22:0 and a reduction in monoenes, as a result of reduced amounts of 16:1 (n-9).

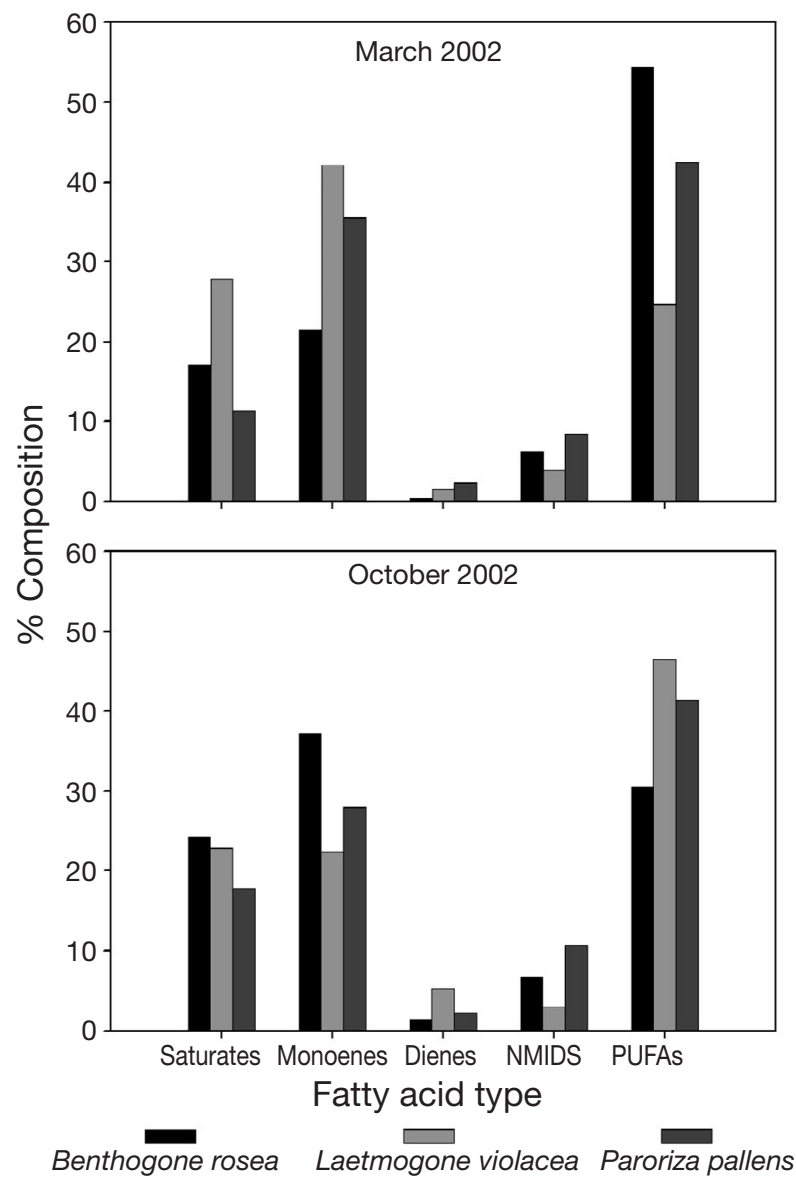

Fig. 5. Benthogone rosea, Laetmogone violacea, Paroriza pallens. Percentage composition of fatty acid types in muscle tissue from holothurians sampled in March 2002 and October 2002 
Table 3. Benthogone rosea, Laetmogone violacea, Paroriza pallens. Mean (SD) percentage fatty acid composition

\begin{tabular}{|c|c|c|c|c|c|c|c|c|c|c|c|c|}
\hline \multirow[t]{3}{*}{ Fatty acid } & \multicolumn{4}{|c|}{ Benthogone rosea } & \multicolumn{4}{|c|}{ Laetmogone violacea } & \multicolumn{4}{|c|}{ Paroriza pallens } \\
\hline & \multicolumn{2}{|c|}{ Mar 02} & \multicolumn{2}{|c|}{ Oct 02} & \multicolumn{2}{|c|}{ Mar 02} & \multicolumn{2}{|c|}{ Oct 02} & \multicolumn{2}{|c|}{ Mar 02} & \multicolumn{2}{|c|}{ Oct 02} \\
\hline & $\bar{x}$ & $\mathrm{SD}$ & $\bar{x}$ & $\mathrm{SD}$ & $\bar{x}$ & $\mathrm{SD}$ & $\bar{x}$ & SD & $\bar{x}$ & SD & $\bar{X}$ & $\mathrm{SD}$ \\
\hline $14: 0$ & 1.39 & 0.41 & 1.91 & 0.53 & 4.35 & 1.07 & 0.79 & 0.24 & 1.82 & 0.34 & 0.53 & 0.21 \\
\hline $14: 1$ & 1.98 & 0.57 & 4.89 & 1.67 & 3.75 & 0.19 & 0.7 & 0.23 & 0.52 & 0.19 & 0.82 & 0.38 \\
\hline $15: 0$ & 1.04 & 0.55 & 1.7 & 0.57 & 1.87 & 0.31 & 0.82 & 0.35 & 0.27 & 0.05 & 0.36 & 0.14 \\
\hline 16:0 DMA & 0.97 & 0.51 & 2.67 & 0.91 & 2.35 & 0.2 & 0.66 & 0.11 & 0.12 & 0.01 & 0.38 & 0.05 \\
\hline $16: 0$ & 4.71 & 1.2 & 5.65 & 0.86 & 5.7 & 0.29 & 2.72 & 0.72 & 3.88 & 3.31 & 2.84 & 0.12 \\
\hline $16: 1(n-9)$ & 1.17 & 0.67 & 1.7 & 0.15 & 1.74 & 0.33 & 0.39 & 0.1 & 8.91 & 1 & 0.72 & 0.07 \\
\hline $16: 1(n-7)$ & 2 & 0.56 & 2.97 & 0.85 & 5.71 & 0.28 & 2.21 & 0.55 & 0.29 & 0.18 & 1.02 & 0.36 \\
\hline $16: 1(n-5)$ & 0.87 & 0.27 & 2.55 & 0.87 & 2.41 & 0.18 & 1.08 & 0.15 & 3.17 & 1.9 & 0.55 & 0.05 \\
\hline $18: 0$ & 5.28 & 0.33 & 5.96 & 0.36 & 5.97 & 0.3 & 4.63 & 0.58 & 2.64 & 1.04 & 5.29 & 0.47 \\
\hline 18:1(n-9) & 3.12 & 0.49 & 4.64 & 0.56 & 7.16 & 1.32 & 4.92 & 0.54 & 8.65 & 2.37 & 3.63 & 0.31 \\
\hline $18: 1(n-7)$ & 4.52 & 0.67 & 7.42 & 1.25 & 5.56 & 0.96 & 3.95 & 0.62 & 3.7 & 3.47 & 9.83 & 0.51 \\
\hline $18: 1(n-5)$ & 0.31 & 0.16 & 1.12 & 0.08 & 0.61 & 0.12 & 1.21 & 0.49 & 1.17 & 0.51 & 1.23 & 0.68 \\
\hline $18: 2(n-6)$ & 0.45 & 0.33 & 1.41 & 0.16 & 1.5 & 0.2 & 4.33 & 1.93 & 2.29 & 1.06 & 2.16 & 0.54 \\
\hline $20: 0$ & 3.35 & 0.48 & 2.47 & 0.58 & 7.27 & 0.25 & 5.86 & 0.74 & 2.02 & 1 & 2.05 & 0.77 \\
\hline 20:1(n-9) & 0.78 & 0.45 & 1.84 & 0.47 & 0.29 & 0.01 & 0.97 & 0.15 & 0.49 & 0.16 & 2.75 & 1.2 \\
\hline $20: 1(n-7)$ & 1.05 & 0.54 & 1.78 & 0.47 & 3.77 & 0.41 & 1.36 & 0.31 & 2.93 & 0.26 & 1.23 & 0.61 \\
\hline $20: 2 \Delta 5,13$ & 0.29 & 0.2 & 2.2 & 0.61 & 0.34 & 0.1 & 0.89 & 0.26 & 0.55 & 0.09 & 0.82 & 0.2 \\
\hline 20:4(n-6) & 31.6 & 2.29 & 16.23 & 2.46 & 21.68 & 2.7 & 22.34 & 4.17 & 29.06 & 0.52 & 30.54 & 1.34 \\
\hline $20: 5(n-3)$ & 17.59 & 0.73 & 9.07 & 1.51 & 1.66 & 0.9 & 11.55 & 2.19 & 9.89 & 1.76 & 8.12 & 0.62 \\
\hline $22: 0$ & 0.35 & 0.19 & 3.44 & 0.46 & 0.36 & 0.07 & 4.89 & 0.53 & 0.6 & 0.25 & 6.37 & 0.33 \\
\hline $22: 1(n-7)$ & 1.23 & 0.46 & 2.27 & 0.55 & 3.62 & 0.35 & 1.47 & 0.34 & 0.55 & 0.2 & 1.06 & 0.36 \\
\hline $22: 2 \Delta 7,15$ & 6.01 & 0.5 & 4.1 & 0.3 & 3.54 & 0.55 & 2.13 & 0.42 & 7.84 & 0.62 & 9.86 & 0.59 \\
\hline 22:5(n-3) & 0.62 & 0.28 & 1.17 & 0.04 & 0.26 & 0.16 & 1.29 & 0.19 & 0.88 & 0.18 & 1.34 & 0.07 \\
\hline $22: 6(n-3)$ & 4.61 & 0.56 & 2.86 & 0.5 & 1.11 & 0.83 & 6.36 & 1.42 & 2.6 & 0.24 & 1.34 & 0.47 \\
\hline $24: 1(n-9)$ & 4.51 & 0.15 & 6.03 & 0.74 & 7.41 & 2.16 & 3.8 & 0.82 & 5.18 & 1.12 & 5.15 & 0.62 \\
\hline Saturates & 17.09 & 3.65 & 23.79 & 4.27 & 27.88 & 2.48 & 20.37 & 3.27 & 11.35 & 6.01 & 17.82 & 2.07 \\
\hline Monoenes & 15.58 & 18.48 & 27.53 & 13.03 & 29.88 & 12.53 & 16.08 & 12.87 & 28.14 & 21.54 & 20.58 & 2.35 \\
\hline Dienes & 0.45 & 0.33 & 1.41 & 0.16 & 1.5 & 0.2 & 4.33 & 1.93 & 2.29 & 1.06 & 2.16 & 0.54 \\
\hline NMIDS & 6.31 & 0.69 & 6.3 & 0.91 & 3.88 & 0.65 & 3.02 & 0.68 & 8.38 & 0.71 & 10.68 & 0.79 \\
\hline PUFAS & 54.42 & 3.85 & 29.34 & 4.51 & 24.71 & 4.59 & 41.56 & 7.98 & 42.42 & 2.7 & 41.34 & 2.5 \\
\hline
\end{tabular}

pre-bloom period and low in the post-bloom period (Fig. 6). This was caused by a significant reduction in 20:5 (n-3) $(F=393.6$, df $=1,10, \mathrm{p}<0.001)$ (Table 4), although the trend was not as evident in Psychropotes longicauda.

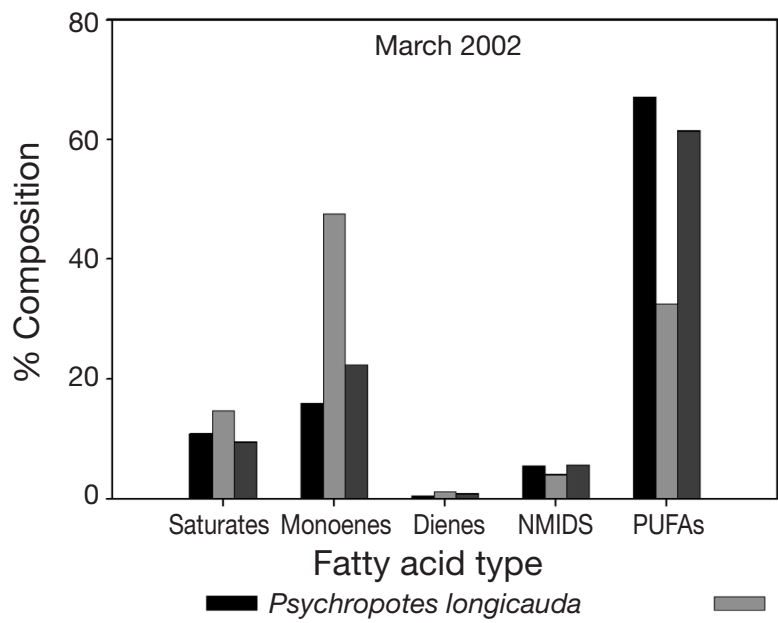

\section{DISCUSSION}

Holothurians are ideal animals for studying the effects of seasonal flux on the deep-sea benthic megafaunal community because (1) they are common

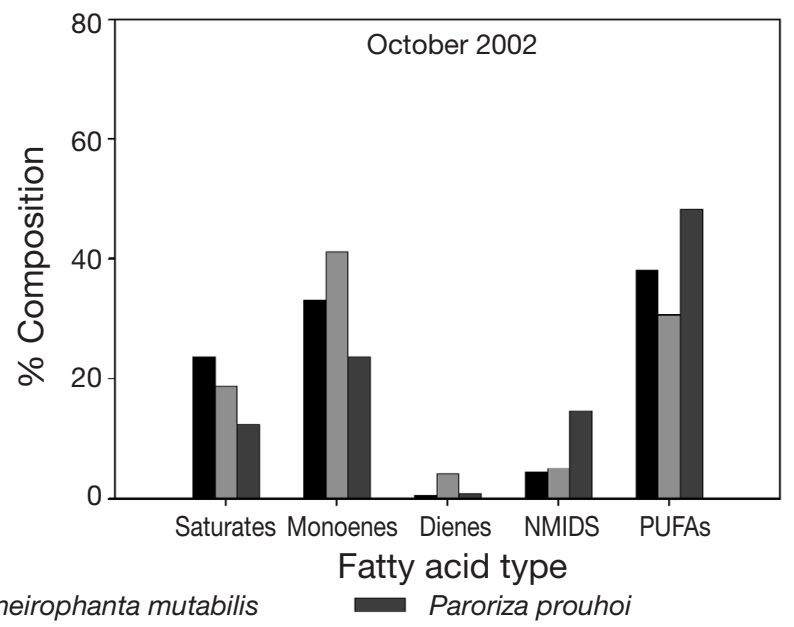

Fig. 6. Psychropotes longicauda, Oneirophanta mutabilis, Paroriza prouhoi. Percentage composition of fatty acid types in muscle tissue from holothurians sampled in March 2002 and October 2002 
Table 4. Psychropotes longicauda, Oneirophanta mutabilis, Paroriza prouhoi. Mean (SD) percentage fatty acid composition

\begin{tabular}{|c|c|c|c|c|c|c|c|c|c|c|c|c|}
\hline \multirow[t]{3}{*}{ Fatty acid } & \multicolumn{4}{|c|}{ Psychropotes longicauda } & \multicolumn{4}{|c|}{ Oneirophanta mutabilis } & \multicolumn{4}{|c|}{ Paroriza prouhoi } \\
\hline & \multicolumn{2}{|c|}{ Mar 02} & \multicolumn{2}{|c|}{ Oct 02} & \multicolumn{2}{|c|}{ Mar 02} & \multicolumn{2}{|c|}{ Oct 02} & \multicolumn{2}{|c|}{ Mar 02} & \multicolumn{2}{|c|}{ Oct 02} \\
\hline & $\bar{x}$ & $\mathrm{SD}$ & $\bar{x}$ & $\mathrm{SD}$ & $\bar{X}$ & $\mathrm{SD}$ & $\bar{X}$ & $\mathrm{SD}$ & $\bar{x}$ & $\mathrm{SD}$ & $\bar{X}$ & $\mathrm{SD}$ \\
\hline $14: 0$ & 0.34 & 0.35 & 1.49 & 0.18 & 1.42 & 0.38 & 0.6 & 0.11 & 0.17 & 0.06 & 0.48 & 0.13 \\
\hline $14: 1$ & 0.35 & 0.18 & 3.4 & 0.57 & 4.01 & 1.52 & 2.22 & 0.32 & 1.01 & 0.45 & 0.84 & 0.1 \\
\hline $15: 0$ & 0.26 & 0.09 & 1.47 & 0.14 & 3.08 & 0.95 & 3.03 & 1.04 & 1.07 & 0.37 & 0.55 & 0.07 \\
\hline 16:0 DMA & 0.29 & 0.12 & 2.6 & 0.18 & 2.24 & 0.8 & 1.22 & 0.17 & 0.54 & 0.26 & 0.31 & 0.04 \\
\hline $16: 0$ & 1.93 & 0.74 & 4.68 & 0.21 & 2.5 & 1.06 & 3.02 & 0.71 & 0.88 & 0.06 & 2.63 & 0.27 \\
\hline $16: 1(n-9)$ & 0.41 & 0.28 & 1.81 & 0.52 & 2.4 & 0.81 & 2.02 & 0.15 & 0.55 & 0.28 & 0.6 & 0.11 \\
\hline $16: 1(n-7)$ & 1.23 & 0.29 & 2.58 & 0.29 & 4.39 & 0.98 & 2.96 & 0.75 & 1.19 & 0.79 & 1.26 & 0.1 \\
\hline $16: 1(n-5)$ & 0.56 & 0.27 & 1.84 & 0.49 & 6.56 & 2.03 & 5.88 & 1.28 & 1.56 & 0.4 & 0.86 & 0.11 \\
\hline $18: 0$ & 4.25 & 2.36 & 5.99 & 0.84 & 2.92 & 0.62 & 6.63 & 2.14 & 2.88 & 0.32 & 3.58 & 0.5 \\
\hline 18:1(n-9) & 1.66 & 0.56 & 2.51 & 0.22 & 3.96 & 1.11 & 5.33 & 0.59 & 0.71 & 0.11 & 1.51 & 0.13 \\
\hline $18: 1(\mathrm{n}-7)$ & 5.58 & 1.29 & 6.66 & 0.19 & 12.92 & 3.05 & 11.24 & 0.37 & 9.36 & 1.85 & 9.4 & 0.62 \\
\hline $18: 1(n-5)$ & 0.58 & 0.35 & 0.62 & 0.27 & 0.56 & 0.49 & 1.99 & 0.29 & 1.7 & 1.61 & 1.36 & 0.13 \\
\hline $18: 2(\mathrm{n}-6)$ & 0.46 & 0.31 & 0.47 & 0.07 & 1.17 & 0.42 & 4.23 & 0.35 & 0.89 & 0.27 & 0.84 & 0.08 \\
\hline $20: 0$ & 1.65 & 0.69 & 3.03 & 0.12 & 1.04 & 0.11 & 0.74 & 0.12 & 0.99 & 0.45 & 0.91 & 0.07 \\
\hline $20: 1(n-9)$ & 0 & 0 & 1.98 & 1.06 & 3.9 & 0.91 & 1.89 & 0.14 & 1.38 & 0.48 & 0.76 & 0.06 \\
\hline $20: 1(n-7)$ & 1.8 & 1.19 & 1.67 & 0.6 & 1.33 & 0.39 & 2.23 & 0.71 & 0.44 & 0.29 & 1.09 & 0.06 \\
\hline $20: 2 \Delta 5,13$ & 0.53 & 0.4 & 0.41 & 0.18 & 0.92 & 0.38 & 2.49 & 0.57 & 0.13 & 0.01 & 0.86 & 0.04 \\
\hline 20:4(n-6) & 39.36 & 8.25 & 14.81 & 0.7 & 14.92 & 3.43 & 9.91 & 1.61 & 22.14 & 1.94 & 25.61 & 0.7 \\
\hline $20: 5(n-3)$ & 19.98 & 5.17 & 15.53 & 0.57 & 12.51 & 1.78 & 12 & 1.14 & 32.17 & 2.71 & 17.24 & 0.67 \\
\hline $22: 0$ & 2.12 & 2.71 & 4.42 & 0.4 & 1.51 & 0.42 & 3.51 & 1.4 & 2.99 & 0.1 & 3.94 & 0.22 \\
\hline $22: 1(n-7)$ & 1.17 & 0.6 & 4.03 & 0.34 & 3.17 & 0.68 & 2 & 0.29 & 0.8 & 0.51 & 0.87 & 0.05 \\
\hline $22: 2 \Delta 7,15$ & 5.01 & 1.77 & 4.08 & 0.36 & 3.11 & 0.57 & 2.61 & 0.24 & 5.6 & 0.24 & 13.88 & 0.92 \\
\hline $22: 5(n-3)$ & 2.27 & 1.29 & 1.26 & 0.2 & 0.99 & 0.1 & 1.08 & 0.35 & 1.21 & 0.05 & 1.51 & 0.21 \\
\hline $22: 6(n-3)$ & 5.63 & 1.06 & 6.54 & 0.37 & 4.11 & 0.78 & 7.69 & 0.72 & 5.91 & 0.5 & 3.94 & 0.4 \\
\hline $24: 1(\mathrm{n}-9)$ & 2.59 & 1.35 & 6.12 & 0.47 & 4.36 & 0.35 & 3.5 & 0.77 & 3.73 & 0.66 & 5.17 & 0.35 \\
\hline Saturates & 10.85 & 7.06 & 23.69 & 2.07 & 14.71 & 4.35 & 18.74 & 5.7 & 9.53 & 1.61 & 12.4 & 1.3 \\
\hline Monoenes & 15.92 & 6.36 & 33.22 & 5.01 & 47.56 & 12.32 & 41.24 & 5.65 & 22.43 & 7.41 & 23.72 & 1.83 \\
\hline Dienes & 0.46 & 0.31 & 0.47 & 0.07 & 1.17 & 0.42 & 4.23 & 0.35 & 0.89 & 0.27 & 0.84 & 0.08 \\
\hline NMIDS & 5.54 & 2.17 & 4.49 & 0.54 & 4.03 & 0.95 & 5.1 & 0.81 & 5.72 & 0.25 & 14.74 & 0.96 \\
\hline PUFAS & 67.23 & 15.77 & 38.13 & 1.84 & 32.53 & 6.09 & 30.68 & 3.82 & 61.43 & 5.19 & 48.3 & 1.98 \\
\hline
\end{tabular}

in the deep sea, and (2) most species feed on fresh detrital material in the upper few millimeters of the sediment. All the species studied here are epibenthic sediment surface feeders and some, such as Benthogone rosea and Amperima rosea, have been shown to feed readily on fresh phytodetritus (Billett et al. 1988, Iken et al. 2001). It would be expected that if the holothurians feed on a seasonal input of fresh material during summer months then their body composition would change with time, with a build-up of labile fatty acids and other compounds during summer months and then a decline during the rest of the year as the compounds are used up. The results presented here indicate that while this may be true for some species, the situation is rather more complex; some holothurian species showed little change in their fatty acid composition during the year while others showed an inverse relationship with periods of phytodetritus deposition.

Polyunsaturated fatty acids (PUFAs) are vital for maintenance, reproduction and growth of deep-sea megafauna. PUFAs are common in many echinoderms in both the deep sea and in shallow water (Takagi et al. 1980, Howell et al. 2003). However, PUFAs are very labile and are generally found only in small quantities in deep-sea sediments (Nichols 2003). Most of the PUFAs arrive on the deep-sea floor in fresh organic matter deposited during the summer months. The seasonal flux of OM to the benthos on the Porcupine Abyssal Plain and in the Porcupine Seabight in the NE Atlantic is well documented (Billett et al. 1983, Lampitt 1985, Lampitt et al. 2001). In August 2001 there was a substantial flux of OM through the water column, as measured by sediment traps moored at $3000 \mathrm{~m}$ at a central locality on the Porcupine Abyssal Plain (Fig. 7). It is not surprising, therefore, that several species showed particularly high proportions of PUFAs in their muscle tissue at this time.

The sediment trap data then showed that there was no further substantial input of fresh OM until May 2002. It would be expected therefore that PUFAs would have been utilised during the winter of $2001 / 2002$ and that they would have been proportionally lower as part of the total fatty acid pool by March 2002. This trend was evident in Amperima rosea and Bathyplotes natans (Fig. 2). In addition, increased proportions of the bacterial biomarker 18:1 (n-7) were 


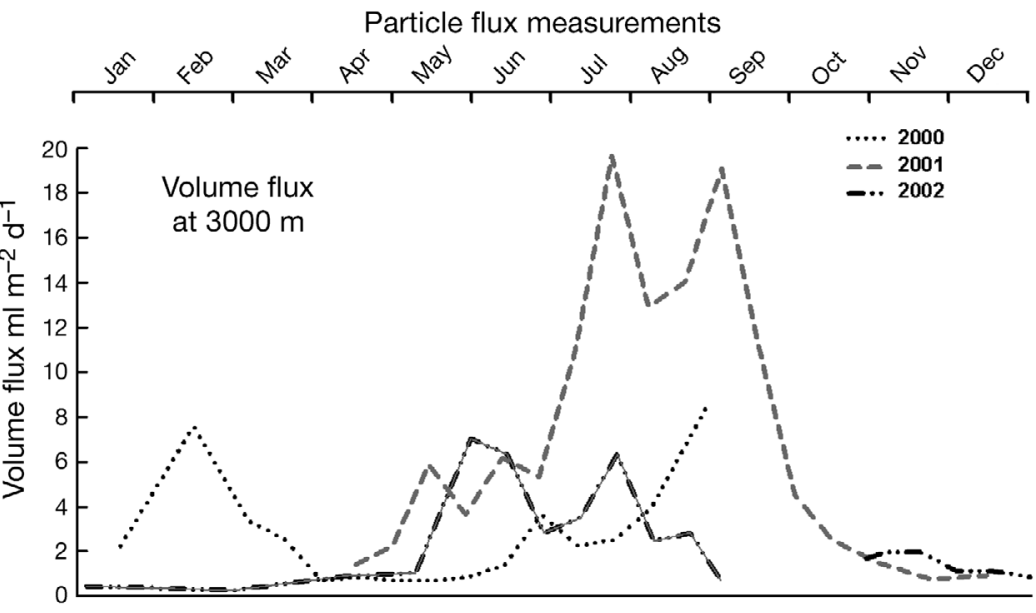

Fig. 7. Interannual volume flux data determined from sediment-trap samples collected from 3000 m depths over Porcupine Abyssal Plain, NE Atlantic Ocean

evident, indicating that these holothurians were more reliant on bacterial food sources at this time. By October 2002, following a further pulse of fresh detritus in the summer of 2002 (Fig. 7) the proportions of PUFAs had increased to levels comparable to August 2001 (Fig. 2; Table 2). Laetmogone violacea showed lower PUFA proportions in March 2002 (25\%) than in October 2002 (42\%) (Fig. 5) This is consistent with the hypothesis that PUFA levels would be higher in periods following the deposition of phytodetritus than at the end of the winter months.

However, in 7 other holothurian species, 4 from abyssal depths and 3 bathyal species, the same seasonal shifts in PUFA proportions were not evident (Fig. 2, 5, 6 \& Tables 2, 3, 4). The abyssal species Oneirophanta mutabilis and Deima validum were shown to have consistently high PUFA proportions in pre-bloom and post-bloom periods. This was also true for the bathyal species Paroriza pallens. The abyssal species Psychropotes longicauda and Paroriza prouhoi and the bathyal species Benthogone rosea contained higher proportions of PUFAs in March 2002 (67, 61, $54 \%$, respectively) than in October 2002 (38, 48 and 29\%, respectively). These results suggest that processes other than just the availability of fresh OM regulate the proportions of PUFAs in the tissues of deep-sea animals.

The presence of PUFAs in body tissues will depend on both the supply of these compounds in detritus and their utilisation in body processes, notably reproduction. It is possible the apparent changes in the proportions of PUFAs are related to the reproductive strategies employed by the various species, and this link was investigated further.

\section{Seasonal shifts in PUFAs: links to reproduction?}

All the species that showed significant changes in fatty acid composition concurrent with the seasonal deposition of OM (Amperima rosea, Bathyplotes natans and Laetmogone violacea) have a relatively small egg size. A. rosea has a maximum egg diameter of $200 \mu \mathrm{m}$ (Wigham et al. 2003a), B. natans $280 \mu \mathrm{m}$ (Tyler et al. 1994) and L. violacea $400 \mu \mathrm{m}$ (Tyler et al. 1985) (Table 5). It seems probable that all these species accumulate and store PUFAs at times when fresh phytodetritus is available. A. rosea has been shown to feed avidly on phytodetritus (Iken et al. 2001), and data from chloropigments in the guts of $L$. violacea indicate that this species also makes use of detritus (Billett et al. 1988).

PUFAs are known to be important in the reproduction of marine invertebrates (Pond et al. 1996, Albessard et al. 2001, Rosa \& Nunes 2002, Wacker \& von Elert 2003), providing a lipid pool for vitellogenesis and development (DeMott \& Muller-Navarra 1997, Wen et al. 2002). The importance of PUFAs in reproduction and development, and particularly for early life stages of marine invertebrates (Pond et al 1996, Albessard et al. 2001), may be as crucial as

Table 5. Summary of holothurian egg sizes and reproductive strategies with data summarized from Billett (1991), Tyler \& Young (1992), Wigham (2002)

\begin{tabular}{|c|c|c|}
\hline Species & $\begin{array}{l}\text { Maximum egg } \\
\text { diameter }(\mu \mathrm{m})\end{array}$ & Reproductive processes \\
\hline \multicolumn{3}{|l|}{ Abyssal } \\
\hline Amperima rosea & 200 & $\begin{array}{l}\text { Opportunistic egg production, rapid } \\
\text { lecithotrophic development }\end{array}$ \\
\hline Oneirophanta mutabilis & 950 & Direct planktonic development \\
\hline Deima validum & 700 & Direct planktonic development \\
\hline Psychropotes longicauda & 4400 & Direct planktotrophic development \\
\hline Paroriza prouhoi & 450 & $\begin{array}{l}\text { Continuous egg production, lecithotrophic } \\
\text { development (hermaphrodite) }\end{array}$ \\
\hline \multicolumn{3}{|l|}{ Bathyal } \\
\hline Bathyplotes natans & 280 & $\begin{array}{l}\text { Quasi-continuous egg production, } \\
\text { lecithotrophic development }\end{array}$ \\
\hline Paroriza pallens & 350 & $\begin{array}{l}\text { Continuous egg production, lecithotrophic } \\
\text { development (hermaphrodite) }\end{array}$ \\
\hline Laetmogone violacea & 400 & Abbreviated lecithotrophic development \\
\hline Benthogone rosea & 750 & Direct development \\
\hline
\end{tabular}


reproductively important carotenoids found within the same holothurian species investigated in this study (Hudson et al. 2003, Wigham et al. 2003b, Hudson 2004), and in other shallow-water holothurians (Matsuno \& Tsushima 1995, Hamel \& Mercier 1999).

Amperima rosea is the most abundant holothurian species on the PAP, following a massive population boom in 1997 (Billett et al. 2001, Wigham 2002). If A. rosea has the ability to select for PUFAs when OM is available, it may allocate the majority of this resource to production of large numbers of small eggs (Table 5) throughout the whole year, in an opportunistic manner. This would deplete the reserves within the body and muscle tissue until the next bloom event the following spring. Wigham (2002) made a similar suggestion based upon the high amounts of reproductively important carotenoids found in this species during post-bloom periods, which subsequently decline during pre-bloom periods.

Bathyplotes natans and Laetmogone violacea showed a significant temporal pattern in PUFAs and also in reproductively important carotenoids (Hudson et al. 2003). These species are not seasonal breeders, but they may allocate PUFAs and reproduce at times when the availability of fresh OM as a source of PUFA and carotenoid pigments is high. To examine this further, the reproductive state of deep-sea holothurians must be investigated along with the biochemical composition of their different body tissues.

In contrast, the reverse pattern of PUFA allocation shown in Psychropotes longicauda, Paroriza prouhoi and Benthogone rosea could also relate to reproduction. Both Psychropotes longicauda and B. rosea have large eggs that develop into a juvenile without a larval stage (Table 5). In the case of $P$. longicauda the eggs are the largest known of all holothurians (Hansen 1975). Direct development in this species may mean that prior to the spring bloom period holothurians accumulate and store all PUFAs available until just before the onset of deposition of phytodetritus in summer. Eggs are developed, depleting PUFAs, so that juveniles developed directly from the egg enter the environment when food resources are high. Tyler et al. (1985, 1992), Tyler \& Billett (1987) and Tyler \& Young (1992) suggested that there is no evidence of seasonal changes in fecundity in these species, but egg numbers are low, so it may be difficult to determine.

The reasons for the changes in the hermaphroditic Paroriza prouhoi are less clear. This species has small eggs (Table 5) and aseasonal reproduction (Tyler et al. 1992). Oocyte frequency data suggest that it produces batches of eggs at certain times of the year, although not entirely related to season. Such 'batch' production may be related to the reproductive 'pairing' behaviour of this species (Tyler et al. 1992).
The abyssal species Deima validum and Oneirophanta mutabilis showed no change in their proportions of PUFAs over time. Both species have similar sized eggs of 700 and $950 \mu \mathrm{m}$ diameter, respectively (Table 5) with evidence of intra-ovarian brooding (Hansen 1975). This strategy may promote continuous supply of eggs, whereby a small number of eggs are slowly and continually released for brooding. This would not cause substantial changes in the proportions of PUFA within the muscle tissue, as they would not need to transfer large levels of lipid at any one time into the gonad. This assumption depends on whether holothurians store lipid in their muscle tissues along with the gonad, as is common in other marine animals (Rosa \& Nunes 2002). As both these species contained high levels of monoenes during the pre-bloom period, predominantly made up of 18:1 (n-7), there is a suggestion that bacterial sources of carbon are ingested during this period (Perry et al. 1979). Some bacteria are also capable of de novo synthesis of 20:4 (n-6), particularly free-living and some endosymbiotic strains (Nichols et al. 1993, Russell \& Nichols 1999), perhaps accounting for some of the increased levels found in all species with high PUFA amounts during periods of low OM flux. A role for bacteria in supplementing nutrition has been suggested for deep-sea holothurians (Manship 1995, Roberts et al. 2000), and other depositfeeding megafauna (Sokolova 2000). The pathways for de novo synthesis of PUFA by piezophilic bacteria that dominate abyssal sediments (Nichols 2003) and accumulate within the intestine of deep-sea holothurians could allow the addition of useful fatty acids 20:5 (n-3) and 20:4 (n-6) to their diets and reproductive needs (Nichols 2003) which, in turn, might also account for the lack of fully season-dependent reproduction (Tyler 1988).

\section{Conclusions}

We have shown that 3 holothurian species from bathyal and abyssal depths have temporally variable fatty acid compositions, which coincide with the strong seasonal fluxes of phytodetrial $\mathrm{OM}$ to the seafloor within the NE Atlantic Ocean. Evidence from fatty acid analysis of muscle tissue from Amperima rosea suggests that this species, although not entirely a seasonal breeder, takes significant advantage of a fresh food source during bloom periods to promote storage of PUFA, perhaps for use in reproductive processes. In contrast, 3 other species from bathyal and abyssal depths showed significantly higher proportions of PUFAs during a pre-bloom period (March 2002). The reproductive patterns of Deima validum and Oneirophanta mutabilis may explain why levels of PUFA 
were maintained over the course of a year. Paroriza pallens also showed little temporal change.

Examination of fatty acid biomarkers has revealed not only evidence that certain species may display a high degree of seasonal bentho-pelagic coupling, but also that deep-sea holothurians display a high degree of interspecific differences in their fatty acid composition that may be related to the differences in reproductive pattern shown across this broad taxon. More work on the biochemistry of reproduction is needed to understand fully how the biochemical needs of deepsea animals determine dietary needs and how this changes temporally and interannually with varying OM fluxes.

Acknowledgements. The authors would like to thank the officers and crew of RRS 'Discovery' and would also like to thank K. Howell for her help with fatty acid analyses and discussion, and the valuable comments and suggestions offered by the anonymous reviewers and the editor. This study was supported by a studentship awarded to I. R. H. by the School of Ocean and Earth Science and The George Deacon Division for Ocean Processes, Southampton Oceanography Centre, University of Southampton.

\section{LITERATURE CITED}

Albessard E, Mayzaud P, Cuzin-Roudy J (2001) Variation of lipid classes among organs of the northern krill Meganyctiphanes norvegica, with respect to reproduction. Comp Biochem Physiol A 129:373-390

Beaulieu SE (2002) Accumulation and fate of phytodetritus on the sea floor. Oceanogr Mar Biol Annu Rev 40:171-232

Billett DSM (1991) Deep-Sea holothurians. Oceanogr Mar Biol Annu Rev 29:259-317

Billett DSM, Lampitt RS, Rice AL, Mantoura RFC (1983) Seasonal sedimentation of phytoplankton to the deep-sea benthos. Nature 302:520-522

Billett DSM, Llewellyn C, Watson J (1988) Are deep-sea holothurians selective feeders? In: Burke RD (ed) Echinodermata: Proc 6th Int Echinoderm Conf, Victoria. Balkema, Rotterdam, p 421-429

Billett DSM, Bett BJ, Rice AL, Thurston MH, Galeron J, Sibuet M, Wolff GA (2001) Long-term change in the megabenthos of the Porcupine Abyssal Plain (NE Atlantic). Prog Oceanogr 50:1-4

Christie WW (1982) Lipid analysis, 2nd edn. Pergamon Press, Oxford

Clarke KR, Warwick RM (1994) Change in marine communities: an approach to statistical analysis and interpretation. Plymouth Marine Laboratory, Plymouth

DeMott WR, Muller-Navarra DC (1997) The importance of highly unsaturated fatty acids in zooplankton nutrition: evidence from experiments with Daphnia, a cynaobacterium and lipid emulsions. Freshw Biol 38:649-664

de Wilde P, Duineveld GCA, Berghuis EM, Lavaleye MSS, Kok A (1998) Late-summer mass deposition of gelatinous phytodetritus along the slope of the NW European Continental Margin. Prog Oceanogr 42:165-187

Ducklow H, Harris R (1993) JGOFS North Atlantic bloom experiment (NABE). Deep-Sea Res II 40:1-8

Folch J, Lees N, Sloan-Stanley GH (1957) A simple method for the isolation and purification of total lipid. J Biol Chem 226:497-509

Ginger ML, Billett DSM, Mackenzie KM, Kiriakoulakis K and 5 others (2001) OM assimilation by holothurians in the deep-sea: some observations and comments. Prog Oceanogr 50:407-422

Gooday AJ (2002) Biological responses to seasonally varying fluxes of organic matter to the ocean floor: a review. J Oceanogr 58:305-332

Hamel JF, Mercier A (1999) Mucus as a mediator of gametogenic synchrony in the sea cucumber Cucumaria frondosa (Holothuroidea: Echinodermata). J Mar Biol Assoc UK 79: 121-129

Hansen B (1975) Systematics and biology of the deep-sea holothurians. Part 1. Elasipoda. Galathea Rep 13:1-262

Harvey HR, Johnston JR (1995) Lipid composition and flux of sinking and size-fractionated particles in Chesapeake Bay. Org Geochem 23:2105-2118

Howell KL, Pond DW, Billett DSM, Tyler PA (2003) Feeding ecology of deep-sea seastars (Echinodermata: Asteroidea): a fatty acid biomarker approach. Mar Ecol Prog Ser 255: 193-206

Hudson IR (2004) Deep-Sea biology food for thought? Examining dietary selection and resource allocation in deep-sea holothurians. PhD thesis, School of Ocean and Earth Sciences, University of Southampton

Hudson IR, Wigham BD, Billett DSM, Tyler PA (2003) Seasonality and selectivity in the feeding ecology and reproductive biology of deep-sea holothurians. Prog Oceanogr 59: 381-408

Iken K, Brey T, Wand U, Voigt J (2001) Food web structure of the benthic community at the Porcupine Abyssal Plain (NE Atlantic): a stable isotope analysis. Prog Oceanogr 50: 383-406

Kiriakoulakis K, Stutt E, Rowland SJ, Vangriesheim A, Lampitt RS, Wolff GA (2001) Controls on the organic chemical composition of settling particles in the north-east Atlantic Ocean. Prog Oceanogr 50:65-89

Lampitt RS (1985) Evidence for the seasonal deposition of detritus to the deep-sea floor and its subsequent resuspension. Deep-Sea Res I 32:885-897

Lampitt RS, Antia AN (1997) Particle flux in deep seas: regional characteristics and temporal variability. DeepSea Res I 46:1377-1403

Lampitt RS, Bett BJ, Kiriakoulakis K, Popova EE, Ragueneau O, Vangriesheim A, Wolff GA (2001) Material supply to the abyssal seafloor in the northeast Atlantic. Prog Oceanogr 50:27-63

Manship BAD (1995) The feeding ecology of deposit-feeding holothurians. PhD Thesis, Queens University, Belfast

Massin C (1982) Food and feeding mechanisms: Holothuroidea. In: Jangoux M, Lawrence JM (eds) Echinoderm nutrition. Balkema, Rotterdam, p 43-55

Matsuno T, Tsushima M (1995) Comparative biochemicalstudies of carotenoids in sea-cucumbers. Comp Biochem Physiol B 111:597-605

Mayzaud P, Virtue P, Albessard E (1999) Seasonal variations in the lipid and fatty acid composition of the euphausiid Meganyctiphanes norvegica from the Ligurian Sea. Mar Ecol Prog Ser 186:199-210

Merrett NR, Marshall NB (1981) Observations on the ecology of two deep-sea bottom-living fishes collected off northwest Africa $\left(08^{\circ} \mathrm{N}-27^{\circ} \mathrm{N}\right)$. Prog Oceanogr 9:185-244

Nichols DS (2003) Prokaryotes and the input of polyunsaturated fatty acids to the marine food web. FEMS Microbiol Lett 219:1-7

Nichols DS, Nichols PD, McMeekin TA (1993) Polyunsatu- 
rated fatty acids in Antarctic bacteria. Antarct Sci 5: 149-160

Perry GJ, Volkman JK, Johns RB, Bavor HJ Jr (1979) Fatty acids of bacterial origin in contemporary marine sediments. Biochim Biophys Acta 43:1715-1725

Pfannkuche O, Lochte K (1993) Open ocean pelago-benthic coupling cyanobacteria as tracers of sedimenting salp feces. Deep-Sea Res I 40:727-737

Pond DW, Harris R, Head R, Harbour D (1996) Environmental and nutritional factors determining seasonal variability in the fecundity and egg viability of Calanus helgolandicus in coastal waters off Plymouth, UK. Mar Ecol Prog Ser 143: 45-63

Pond DW, Bell MV, Harris RP, Sargent JR (1998) Microplanktonic polyunsaturated fatty acid markers: a mesocosm trial. Estuar Coast Shelf Sci 46:61-67

Raymont JEG (1980) Plankton and productivity in the oceans, 2nd edn, Vol 1, Phytoplankton. Pergamon Press, Oxford

Rice AL, Billett DSM, Thurston MH, Lampitt RS (1991) The Institute of Oceanographic Sciences biology programme in the Porcupine Seabight-background and general introduction. J Mar Biol Assoc UK 71:281-310

Roberts D, Gebruk A, Levin V, Manship BAD (2000) Feeding and digestive strategies in deposit-feeding holothurians. Oceanogr Mar Biol Annu Rev 38:257-310

Rosa R, Nunes ML (2002) Biochemical changes during the reproductive cycle of the deep-sea decapod Nephrops norvegicas on the south coast of Portugal. Mar Biol 141: 1001-1009

Russell NJ, Nichols DS (1999) Polyunsaturated fatty acids in marine bacteria-a dogma rewritten. Microbiology (Reading) 145:767-779

Sargent JR, Parkes RJ, Harvey-Mueller I, Henderson RJ (1987) Lipid biomarkers in marine ecology. In: Sleigh MA (ed) Microbes in the sea. Ellis Harwood, Chichester, p 119-138

Sibuet M, Monniot C, Desbruyères D, Dinet A, Khripounoff A, Rowe GT, Segonzac M (1984) Peuplements benthiques et caractéristiques trophiques du milieu dans la plaine abyssal de Demerara dans l'Océan Atlantique. Oceanol Acta 7:345-358 (in French with English abstract)

Sokolova MN (2000) Feeding and trophic structure of deepsea macrobenthos. Smithsonian Institution Libraries, Washington, DC

Takagi T, Eaton CA, Ackman RG (1980) Distribution of fatty acids in lipids of the common Atlantic sea urchin Stron-

Editorial responsibility: Lisa Levin (Contributing Editor), La Jolla, California, USA gylocentrotus droebachiensis. Can J Fish Aquat Sci 37: 195-202

Tyler PA (1988) Seasonality in the deep-sea. Oceanogr Mar Biol Annu Rev 26:227-258

Tyler PA, Billett DSM (1987) The reproductive ecology of elasipodid holothurians from the NE Atlantic. Biol Oceanogr 5: 273-296

Tyler PA, Young CM (1992) Reproduction in marineinvertebrates in stable environments - the deep-sea model. Invertebr Reprod Dev 22:185-192

Tyler PA, Muirhead A, Billett DSM, Gage JD (1985) Reproductive biology of the deep-sea holothurians Laetmogone violacea and Benthogone rosea (Elasipoda: Holothurioidea). Mar Ecol Prog Ser 23:269-277

Tyler PA, Young CM, Billett DSM, Giles LA (1992) Pairing behaviour, reproduction and diet in the deep-sea holothurian genus Paroriza (Holothuroidea). J Mar Biol Assoc UK 72:447-462

Tyler PA, Eckelbarger K, Billett DSM (1994) Reproduction in Bathyplotes natans (Holothurioidea, Synallactidae) from bathyal depths in the northeast and western Atlantic. J Mar Biol Assoc UK 74:383-402

Virtue P, Mayzaud P, Albessard E, Nichols P (2000) Use of fatty acids as dietary indicators in northern krill, Meganyctiphanes norvegica, from northeastern Atlantic, Kattegat, and Mediterranean waters. Can J Fish Aquat Sci 57: $104-114$

Wacker A, von Elert E (2003) Food quality controls reproduction of the zebra mussel (Dreissena polymorpha). Oecologia 135:332-338

Wen XB, Chen LQ, Zhou ZL, Ai CX, Deng GY (2002) Reproduction response of Chinese mitten-handed crab (Eriocheir sinensis) fed different sources of dietary lipid. J Comp Physiol B 172:455-465

Wigham BD (2002) The 'Amperima event': analysis of community change in the abyssal northeast Atlantic Ocean. PhD thesis, University of Southampton

Wigham BD, Tyler PA, Billett DSM (2003a) Reproductive biology of the abyssal holothurian Amperima rosea: an opportunistic response to variable flux of surface derived organic matter? J Mar Biol Assoc UK 83:175-188

Wigham BD, Hudson IR, Billett DSM, Wolff GA (2003b) Is long-term change in the abyssal northeast Atlantic driven by qualitative changes in export flux? Evidence from selective feeding in deep-sea holothurians. Prog Oceanogr 59:409-441

Submitted: October 20, 2003; Accepted: June 18, 2004

Proofs received from author(s): October 18, 2004 